\title{
ЎЗБЕК ТИЛИДА ҚОН - ҚАРИНДОШЛИК ТЕРМИНЛАРИНИНГ ПАЙДО БЎЛИШ ДАВРИГА КЎРА ТИПОЛОГИЯСИ
}

\author{
Nafisa JALILOVA*
}

\begin{abstract}
Аннотация
Маълумки, тилнинг луғавий қатлами фонетика ва морфологияга нисбатан тез ўзгарувчан бўлиб, асрлар оша даврга хос бўлган ўзгаришларни ўзида ёрқин акс эттириб боради. Қон-қариндошлик терминлари инсоният тарихининг энг қадимги давридан ибтидоий жамият тузумига мансуб бўлиб, хали мулкчилик тизими амалга ошмаган даврда пайдо бўла бошлаган. Ўзбек тили хам бундан мустасно эмас. Ўзбек тилидаги қон қариндошлик терминларининг яратилган давридан то шу кунга қадар тарихий тараққиётини куйидагича гурухлар ажратиш мумкин: а) тарихий терминлар-ўзбек тилида тарихда кенг кўлланиб, хозирда умуман ишлатилмайдиган қон-қариндошлик терминлари; б) қадимий терминлар-ўзбек тил учун асос бўлган қадимдан мавжуд бўлиб хозирда хам қўланувчи қон-қариндошлик терминлари; янги терминлар-тилнинг синхроник нормалари шаклланиши даврида пайдо бўлган қон - қариндошлик терминлари. Мақолада ушбу гурухлар алохида тахлил қилинган.
\end{abstract}

Калит Сўзлар: Ўзбек Тили, Ўзбек Тилшунослиги, Туркий Тиллар, Луғавий Қатламлар, Қон-Қаридошлик Терминлари, Тарихий Қон-Қаридошлик Терминлари, Қадимий Қон-Қаридошлик Терминлари, Янги Қон-Қаридошлик Терминлари, “Девону Луғатит Турк".

\section{ÖZBEK TÜRKÇESINDEKİ AKRABALIK TERIMLERINIIN OLUSMMA DÖNEMINE GÖRE TIPOLOJISI}

\section{Özet}

Bilindiği gibi dilin kelime hazinesi onun fonetik ve morfolojik yapısına göre hızla değişen, yüzyılların dildeki etkisini açık bir şekilde yansıtan bir oluşumdur. Akrabalık terimleri insanlık tarihinin en eski çağlarında henüz mülkiyet sisteminin uygulamaya konulmadığı bir dönemde-ilkel toplumda dilde şekillenmeye başlamıştır. Bu süreç tüm dillerde olduğu gibi Özbek Türkçesinde de yaşanmıştır. Özbek Türkçesindeki akrabalık terimlerini şekilleniş ve kullanılış dönemini aşağıdaki gibi üç gruba ayırabiliriz: a) Arkaik terimler - Özbek Türkçesinin çeşitli tarihî devirlerinde kullanılan, şimdilik hiç kullanılmayan terimler; b) Eski terimler Özbek Türkçesindeki çağdaş akrabalık terimlerinin köklerinin dayandığı en eski temel terimler; c) Yeni terimler - Özbek Türkçesinin senkron dil normlarının oluşumunda şekillenen akrabalık terimleri. Bu makalede bu gruplardaki terimler ayrı ayrı incelenmiştir.

Anahtar Sözcükler: Özbekçe, Özbek Dilbilimi, Türk Dilleri, Dilin Kelime Hazinesi, Akrabalık Terimleri, Arkaik Akrabalık Terimleri, Eski Akrabalık Terimleri, Yeni Akrabalık Terimleri, "Devonu Luğatit Türk".

\footnotetext{
" Semerkant Devlet Üniversitesi Özbek Dilbilimi Bölümü, Semerkant / ÖZBEKİSTAN, el - mek: nafisajalilova1978@gmail.com

(D) ORCID ID: https://orcid.org/0000-0001-6184-3886
} 


\title{
TYPOLOGY OF KINSHIP TERMS BY PERIOD OF OCCURRENCE IN UZBEK LANGUAGE
}

\begin{abstract}
As is know, the lexical composition of the language changes rapidly in contrast to phonetics and morphology, it reflects the changes that have taken place in the language for centuries. The term of kinship appeared in the earliest period of human history - in a primitive society, at the time when system of private property had not yet emerged. Naturally, the Uzbek language is not an exception. The historical period of forming of kinship terms in Uzbek language is divided into the following groups: a) archaic terms - commonly used in the history of the Uzbek language, now not use in speech practice; b) ancient terms - oldest terms that are used in speech practice; new terms - terms of kinship, which appeared in the formation of synchronous norms of the Uzbek language. In the article, these moments were specially analyzed.
\end{abstract}

Key Words: Uzbek Language, Uzbek Linguistics, Turkic Languages, Lexica, Kinship, Historical Kinship Terms, Ancient Kinship Terms, Contemporary Kinship Terms, "Devonu Lugatit Turk".

Қон-қариндошлик терминлари (ҚҚТ) инсоният тарихининг энг қадимги давридан ибтидоий жамият тузумига мансуб бўлиб, хали мулкчилик тизими амалга ошмаган даврда пайдо бўла бошлаган. У ўша жамиятдаги қариндошлик муносабатларининг умумий тушунчаларини ифодалаган. Д.А.Ольдероггеннинг таъкидлашича, қариндошлик тизимидаги авлодлар беш турга бўлинган: 1) мен ва ака-укаларим, опа-сингилларим; 2) отам, онам ва уларнинг авлодлари; 3) менинг бобом ва унинг авлодлари; 4) менинг фарзандаларим; 5) менинг барча набираларим.

Қолган авлодлар тан олинмаган ва улар жинсий фарқ қилинмаган. Бу даврда қудаандачилик муносабатлари шаклланмаган, шунинг учун қон-қариндошлик терминларининг бошқа турлари хисобга киритилмаган (Olderogge, 1951:28).

Маьлумки, тилнинг луғавий қатлами фонетика ва морфологияга нисбатан тез ўзгарувчан бўлиб, асрлар оша даврга хос бўлган ўзгаришларни ўзида ёрқин акс эттириб боради. Шу нуқтаи назардан қараганда ҚҚТ лексиканинг бошқа қатламларига нисбатан турғун ва консерватив характерга эга бўлиб, улар семантикасидаги силжишлар (торайиш, кенгайиш)ни хисобга олмаганда ўзларининг энг қадимги, архаик шаклини сақлаб қолган бўлади. Масалан, Г.Айдаровнинг кўрсатишича, Ўрхун-Енисей (Энасой) ёдномаларида қайд этилган ҚҚТларидан 90 фоизга яқини (булардан айримлари фонетик ўзгаришга учраган холда) хозирги туркий тилларнинг кўпчилигида мавжуддир (Aydarov, 1971: 136). Хақиқатдан, Ўрхун-Энасой ёзма ёдгорликлари тилида қайд этилган $a m a, a \partial a$, ана, аба, ача, овул, қыыз, ақа, синил, ини, эр, қатун, йигит, қарындаш сингари ҚҚТлари хозирги туркий тиллар, шу жумладан, ўзбек тили ва шеваларида хам у ёки бу фонетик ўзгаришга учраган холда фаол кўлланиб келмокда.

Ўзбек тилшунослигида ҚҚТлари жуда қадимий тарихга эга бўлиб, ўз таркибида яратилиш даврига кўра хатто ёзма ёдгорликларда хам қайд қилинган шаклларини сақлаб келаётганлиги тарихий лексик, диалектал хамда махсус ҚҚТлар орқали ифодалаб келиши билан қимматбахо манба вазифасини ўтайди. Шунга қарамай мазкур терминлар хозирга қадар лингвистик нуқтаи назаридан махсус текшириш объекти сифатида ўрганилмаган.

Бундан ўн аср муқаддам ёзилган Махмуд Кошғарийнинг “Девону луғот-ит турк”идаги барча ҚҚТнинг бешдан тўрт қисми ўзбек тили ва унинг турли шеваларида 
қарийб хеч қандай лексик-семантик ўзгаришсиз сақланиб қолганлиги кузатилмоқда. Жумладан, инсонлар ўртасидаги қариндош-уруғчилик муносабатларини ифодаловчи ҚҚТ хам туркология тарихида биринчи бўлиб мазкур асарда изохланган (Koşgariy, 1967: 9-385). “Девон”дан кейин яратилган асарларда қон-қариндошлик терминларига оид фикр ва мулохазаларнинг юзага келишида “Девону луғотит турк” асаридаги маълумотлар замин бўлган, десак муболаға бўлмайди.

С.Муталлибов тил тарихи ва лексикасига бағишланган монографиясида тарихий манбаларда қайд қилинган ота, она, бола, у̌zuл, қиз, набира каби қон-қариндошлик терминларини лексикология тарихи билан боғлаб тахлил қилади (Mutallibov, S., 1959: 139-140). Т.3.Мирсоатов ўзбек тилининг қирқ шеваси (Mirsoatov 1953, I: 127-128). Ш.Афзалов Паркент шевасида қўлланувчи қариндошлик терминлари англатган маънолари хақида қисман тўхталиб ўтади (Afzalov 1953: 175-176).

Ўзбек тилидаги сўзларни пайдо бўлиш даврига кўра гурухлаш учун сўзнинг тилда пайдо бўлиш даври, кўлланиш муддати хисобга олинади. Тилнинг муайян даври учун луғавий норма бўлган сўзлар тил ривожининг бошқа бир даври учун норма хисобланмаслиги мумкин. Бу холат луғат таркибидаги бир қатор сўзларнинг эскиришига, сўз даврнинг фактига айланиб қолишига ва хатто кейинчалик тамоман унутилишига олиб келади. Сўзларни тилда пайдо бўлиш даврига кўра гурухлаш тил луғат таркибидаги турғун луғавий қатламларни ёки янги луғавий бирликларни белгилашга имкон беради.

Қон-қариндошлик терминларини пайдо бўлиш даврига кўра гурухлашдан асосий мақсад, мазкур терминларнинг энг қадимий шаклларини, тарихий вариантларини аниқлаш хамда хозирги ўзбек тилида қўлланувчи қон-қариндошлик терминларининг ясалиш, пайдо бўлиш манбаларини белгилашдан иборат.

Қон-қариндошлик терминлари келиб чиқиш тарихига кўра қадимий бўлиб, улар туркий халқларда хали оила-қариндошчилик муносабатлари шаклланмасдан бурунги, қабила-уруғчилик муносабатлари шаклланаётган дастлабки босқич давринии ифода этувчи атамалар сифатида яратила бошлаган.ҚҚТнинг тарихий тараққиётини ўрганиш учун уларни пайдо бўлиш даврига кўра гурухлаш тақозо этилади. Шунга кўра қонқариндошлик терминлари қуйидагича гурухларга ажратиш мумкин:

1. Тарихий терминлар-ўзбек тилида тарихда кенг кўлланиб, хозирда умуман ишлатилмайдиган қон-қариндошлик терминлари.

2. Қадимий терминлар-ўзбек тил учун асос бўлган қадимдан мавжуд бўлиб хозирда хам кўланувчи қон-қариндошлик терминлари.

3. Янги терминлар-тилнинг синхроник нормалари шаклланиши даврида пайдо бўлган қон - қариндошлик терминлари.

Тарихий терминлар ўзбек тилининг муайян даврида кўлланган, аммо кейинчалик тилдан чиқиб, хозирги замон ўзбек тилида учрамайди. Бундай терминларни тарихий манбалар асосида аниқлаш мумкин. Турколог-олимларнинг туркий тилларда кўлланувчи қон-қариндошлик терминлари бўйича олиб борган илмий кузатишлари асосида тўплаган материаллари, яратган асарларини ўрганганимизда туркий тиллар билан бир қаторда ўзбек тилида кўлланган мазкур терминларнинг келиб чиқиш ва тарихий тараққиёти хусусида баъзи маълумотларни олдик. Туркий тилларга қон-қариндошлик терминларининг баъзилари туркий бўлмаган (Хинд-Европа, Мўғул, Ганован, Африка) тилларидан ўзлашган бўлиб, туркий тилларнинг тил хусусиятларига хос равишда талаффуз қилина бошлаган. Лекин туркий тилларнинг ўзиники бўлган қон- қариндошлик терминлари хам мавжуд бўлган. Йиллар ўтиши билан бу (ўзлашган ва ўзиники бўлган) терминлар ўз шакл ва баъзилари маъносини ўзгартириб туркий тиллар, хусусан, ўзбек тилининг лексик таркибидан ўрин эгаллаган. Хозирда эса уларнинг айримлари тамоман тилдан чиққан, баъзилари бошқа терминларнинг ясалшига асос бўлса, яна бир қисми 
ўзгаришсиз (фонетик хусусиятини хисобга олмаганда) сақланиб қолган бўлиб, тилнинг фаол сўзлари сифатида кўлланилмокда. Ана шундай тилдан тамоман чиқиб кетган терминларга куйидагиларни кўрсатиш мумкин: йотаз-хотин, аёл, йурч-қайин, хотиннинг кичик укаси, йегин-жиян, набира, кудаз-аёл, урагуm-аёл, хотинлар, ава-она, ойабақайинсингил, көку//көкяй-хола, тунур- куда, аштал угул-кенжа ўғил, эгат-никох кечаси келин ёнида хизмат қилувчи хотин, чоново-амаки, тоға, авачча-ини, жиян каби. Махмуд Кошғарий «Девон»ида хам бундай сўзларни кўриш мумкин: кic//kici-хотин (I,318), намїжа-божа (I, 417), iri-ака; эрнинг катта акаси (I, 114), балдір овул-ўгай ўғил (I, 425), imlap-хотинлар (I, 140), гәнч-бола (II, 351), бачал-акавачча (I, 373), эгатlik-келин (I, 164), әкә-опа (I, 116), әчі- кекса хотин (I. 114), әвлук-хотин (I, 252), јирі-хотиннинг ўғил укаси (III, 13). Бу ҚҚТ хозирги ўзбек тилида тамоман кўлланилмайди.

Бундай архаик ҚҚТ Алишер Навоий асарлари тилида хамда ўзбек мумтоз адабиёти намуналари тилида кўплаб учрайди: абушқ̧-эр, чол, эран- эрлар, мардлар, ароис- келинлар, ахқфод-неваралар, бин,бинни- ўғил, ўғли, валад-бола, завжа-хотин, завжи-эр, инос-аёллар, хотинлар, хол-тога ва бошқалар (Navoiy asarlari luğati, 1972; Özbek klassik adabiyoti asarlari uchun qisqaça luğat, 1972).

Қадимий терминларни умумтуркий сўзлар деб айтишимиз хам мумкин, чунки хар бир туркий тилнинг лексикасини бойишида умумтуркий сўзларнинг ўрни катта. Албатта, бу умумтуркий сўзларнинг хар бир туркий тилда сақланиб қолиш даражасига боғлиқ. Масалан, Г. Айдаровнинг кўрсатишича, Ўрхун-Енисей ёдномаларида қайд этилган сўзлардан 90 фоизга яқини (буларнинг айримлари фонетик ўзгаришга учраган холда) туркий тилларнинг кўпчилигида мавжуд (Aydarov, 1971: 136).

Дархақиқат, Ўрхун-енисей ёдномалари тилида қайд этилган ата, aдa (ота), анна(она), аба(опа), ача(буви), овул(уувил), қызз(қиз), ақа(ака), сиұил(сингил), ини, эр, келин, құрындаш (қариндош) сингари терминлар туркий тиллар билан бир қаторда ўзбек тили ва унинг шеваларида фаол сўзлар сифатида қўлланилмокда.

Шунингдек, бундан қарийб 1000 йил муқаддам ёзилган Махмуд Кошғарийнинг «Девон»идаги барча қариндошлик терминларининг бешдан тўрт қисми хозирги замон ўзбек тили ва унинг шеваларида хеч қандай лексик-семантик ўзгаришсиз (баъзилари бундан мустасно эвлук, ганч, кіс) сақланиб қолган: балдыв - хотиннинг синглиси, әр - эр киши, әнә - она, өгај-ўгай, қіз, өгај овул, өгај ата - ўгай, ўгай қиз, ўгай ўғил, ўгай ота, йанга - янга, іні - ини, ука, дәдә - дада, ота, йазна - катта киз қардошнинг эри, кэлін келин (Koşgariy, 1960-63, I, III: 426, 119, 144, 390, 119, 239, 113, 114, 315, 256, 213, 12 , 384) кабилар.

В.В.Радлов, Э.В.Севортян хамда Л.З.Будаговлар томонидан яратилган луғатларни кузатганимизда, хақиқатан, ушбу терминлар туркий тилларга, шу жумладан, ўзбек тилига хам қадимдан қариндошлик муносабатларини ифодалаш учун қўлланиб келаётгани, уларнинг луғавий маъноси хамда фонетик шакллари деярли ўзгармаганлиги фақат (хозирда) уларнинг маъно доираси аста-секин кенгайиб бораётганлиги тўғрисидаги фикр ва мулохазаларнинг қанчалик тўғри эканлигига ишонч хосил қилдик. Масалан, овава//обава термини амаки маъносида ишлатилган, хозир бу термин Наманган тип шеваларида шу маънода сақланиб қолган. Ача термини она, опа, буви маъноларида ишлатилган, хозирда бу сўз Наманган ва Фарғона шеваларида опа ва буви маъноларида учрайди. Бундан ташқари, қон-қариндошлик терминларининг хосил бўлишида асос бўлиб келган кўпгина терминларни аниклаб олдик. Жумладан, почча термини маъносида дастлаб езна, жезда сўзлари кўлланилган, олимларимизнинг фикрича, ба сўзи қадимда, «катта, улуғ» маъносини англатган, ача сўзи эса ака, амаки маъноларини ифодалаган кишилар ўз акасини опасининг эридан ажратиш мақсадида ба ача деб мурожаат қилган ва бу сўз фонетик ўзгаришларга юз тутиб бачча - пачча - почча шаклига келиб қолган. 
Келин сўзи орқали келинойи (янга), келинчак, келинбиби, кинчаби (янга маъносида шеваларда) терминлари хосил қилинган. Шунингдек, амаки-отанинг ака-укалари маъносини англатувчи сўз хам қадимги туркий тилда ота маъносини англатувчи ама сўзига ака терминини қўшиш орқали хосил бўлган, чунки сўзловчи отасининг акасини отасидан фарқлаш мақсадида ама ака сўзларидан фойдаланган ва бу сўз ўзбек тилида ама ака - амака - амак, амаки шаклида талаффуз қилина бошлаган. Қайин, куда сўзлари билан хам бир неча янги терминлар юзага келганини айтиш мумкин: қ̧айинота, қ̧айнона, қุайинсингил, қ̧айинова, қ̧айинопа, куда хола, куда бува, кудавай каби.

Янги терминлар деб биз ўзбек тилининг туркий тиллардан фарқли равишда ўзбек тилининг мустақил тил бўлиб шаклланган давридан то шу бугунга қадар бу тилда ясалган, пайдо бўлган терминларни тушунамиз. Яъни бу терминлар ўзбек тилининг ўзиники бўлган ўзбекча сўзлар хисобланади. Бундай сўзлар ўзлашган сўзлардан фарқланади.

Юқорида айтиб ўтганимиздек, қон-қариндошлик терминларининг юзага келишида қадимги терминлар асосий манба бўлиб хизмат қилган. Ўзбек тилининг мустақил тараққиёти давомида юзага келган терминлар ана шу терминлар асосида яратилган бўлиб, улар семантикаси хамда структураси жихатдан ўзига хослиги билан характерланади. Улар куйидагилар: ичкуёв, қарши қуда, вакил ота, катта ота, катта она (ойи), опповойи, холомойи, келинойи, опача, аммавачча, амакивачча, тогавачча, холавачча, оппов дада, овайни кабилар.

\section{Адабиётлар}

AYDAROV, G., (1971). Yazık Orhonskıh pamyatnikov drevnetyurkskoy pismennosti VIII veka. Alma-ata.

KOŞGARIY, M., (1960-1963). Devonu Lugatit Türk: I, II, III. -Toshkent: Fan.

KOŞGARIY, M., (1967). Devonu Lugatit Türk: Indeks Luğat. -Toshkent: Fan.

OLDEROGGE, M., (1951). Malayskaya sistema rodstva // Rodovoe obshestvo. Materiall İssledovaniya. M.

MUTALLIBBOV, S. M., (1959). Morfologiya va leksika tarihidan qisqaça oçerk. Toşkent: ÖzFA Naşriyati.

MIRSOATOV, T. Z., (1953). Özbek tilining Qirq şevasi // Özbek Dialektologiyasidan Materiallar, I. - Toşkent.

AFZALOV, Ş., (1953). Özbek tilining Parkent şevasi // Özbek Dialektologiyasidan Materiallar. I. Toşkent.

Navoiy Asarlari Luğati. 1972.

Özbek Klassik Adabiyoti Asarlari Uchun Qisqaça Luğat. 1972. 